
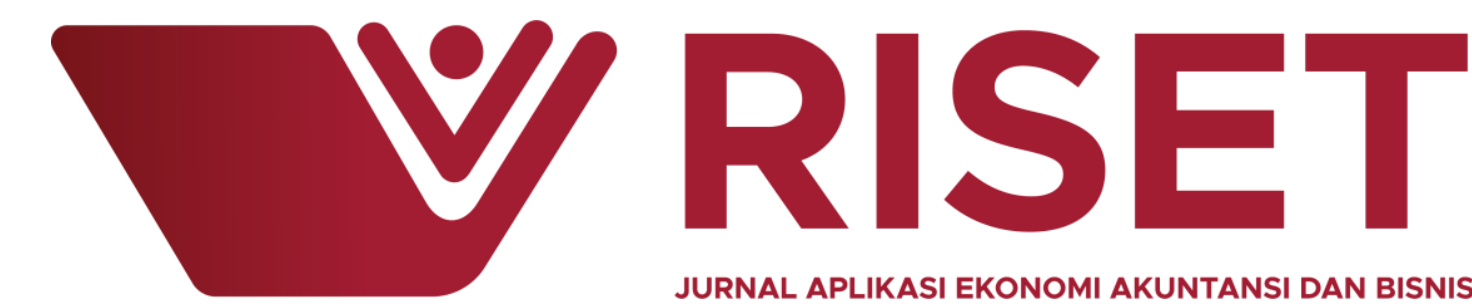

JURNAL APLIKASI EKONOMI AKUNTANSI DAN BISNIS

\title{
Analisis Dampak Pengumuman Dividen Terhadap Perubahan Harga, Abnormal Return, Dan Volume Perdagangan Saham Sebelum Dan Sesudah Pembagian Dividen Bank Pembangunan Daerah Jawa Timur Tbk Tahun 2015-2017
}

\author{
Amrulloh $^{1)}$, Muhammad Abdul Muis ${ }^{2)}$ \\ ${ }^{1,2)}$ STIE Kesatuan Bogor
}

https://doi.org/10.35212/277623

\begin{abstract}
ARTIKEL INFO
ABSTRACT

Analisis Dampak Pengumuman Dividen Terhadap Perubahan Harga, Abnormal Return, Dan Volume

Perdagangan Saham Sebelum Dan Sesudah Pembagian Dividen Bank Pembangunan Daerah Jawa Timur Tbk Tahun 2015-2017

Submitted: JANUARI 2019

Accepted:

MARET 2019

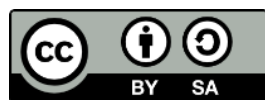

This study aimed to analyze the differences between stock prices, abnormal return and trading volume before and after dividend payout of the Bank Pembangunan Daerah Jawa Timur Tbk.

The research methodology used is quantitative method with panel data types (cross section and time series) and the source of data derived from secondary data obtained from the Indonesia Stock Exchange. Mechanical sampling using purposive sampling method with daily data and the study period from 2015 to 2017. The data analysis technique used is the calculation of the share price, abnormal stock returns and trading volume, the study of events from 40 working days before the event, period, and during the 20 working days after the announcement of the dividend payout, as well as two different test average of pairs (t-test) to see the closeness of the relationship between the two variables with a significance level of 5\%.

The results of this study indicate that the stock price method approach the results obtained there are differences in stock prices before and after dividend payout of Bank Pembangunan Daerah Jawa Timur Tbk period 2015 to 2017. Meanwhile, the abnormal return approach the results obtained there is no difference of abnormal return before and after dividend payout of Bank Pembangunan Daerah Jawa Timur Tbk period 2015 to 2017. Similarly, the volume of stock trading method approach result that there is no difference in the volume of stock trading before and after dividend payout of Bank Pembangunan Daerah Jawa Timur Tbk period 2015 and 2016. But the result in 2017 show that there are differences in trading volume of the stock before and after the dividend payout of Bank Pembangunan daerah jawa Timur Tbk.
\end{abstract}

Keywords : Dividend, Price Stock, Abnormal Return, Trading Volume Email:.bigulloh@gmail.com ${ }^{1}$, Muhammad.muis@yahoo.co.id ${ }^{2}$ 


\section{PENDAHULUAN}

Perkembangan pasar modal di Indonesia saat ini semakin menunjukan peningkatan dan berkembang menjadi salah satu sumber pendanaan jangka panjang maupun jangka pendek bagi dunia usaha dan pemerintah. Berbagai program seperti pembangunan infrastruktur pun turut didorong menggunakan pendanaan dari pasar modal. Otoritas Jasa Keuangan (OJK) menyatakan, pasar modal Indonesia kini telah berkembang sangat pesat. Bahkan sudah menjadi salah satu tujuan investasi menarik bagi para investor baik dari dalam maupun luar negeri. Hal ini dilihat dari jumlah investor yang semakin meningkat yang mempercayai pasar modal sebagai tempat untuk berinvestasi. Pasar modal dinilai mampu untuk memberikan tingkat return yang positif dalam berinvestasi. Selain itu bagi perusahaan, peran pasar modal sangat dibutuhkan dalam penyediaan dana jangka panjang.

Pasar modal memiliki dua fungsi sekaligus yaitu, fungsi pertama pasar modal adalah sebagai ekonomi karena pasar modal menyediakan fasilitas untuk mempertemukan dua orang yang berkepentingan, yaitu pihak yang memiliki dana lebih (investor) dan pihak yang memerlukan dana penerbit. Fungsi kedua pasar modal adalah memberikan imbalan (return) bagi investor sesuai dengan investasi yang ditanamkan di suatu perusahaan. Dalam keputusan investasi saham, investor mengharapkan dividen dan hasil dari capital gain.

Investor merupakan salah satu hal yang sangat penting untuk suatu perusahaan yang telah go public. Hal ini disebabkan karena para investor adalah sumber dari modal perusahaan atas saham-saham yang dimiliki investor tersebut. Para investor biasanya mencari informasi perusahaan terlebih dahulu sebelum mereka memutuskan untuk menginvestasikan modalnya di dalam perusahaan atau tidak, baik dalam bentuk kepemilikan saham maupun dalam bentuk investasi lainnya. Salah satu informasi yang mencerminkan kondisi internal sebuah perusahaan adalah pergerakan harga saham di bursa efek. Sedangkan pergerakan harga saham dipengaruhi oleh informasi-informasi yang mempengaruhi persepsi para investor. Hal inilah yang menjadi salah satu pusat perhatian para investor sebelum mengambil keputusan. Maka wajar jika setiap perusahaan berusaha menciptakan reputasi yang baik di mata investor dengan harapan agar investor ingin menginvestasikan dananya pada perusahaan melalui pembelian saham yang dicatatkan di bursa efek.

Informasi mengenai faktor-faktor yang dapat mempengaruhi harga saham sangat penting bagi spekulator ataupun investor dan salah satu faktor yang dapat mempengaruhi harga saham yaitu kondisi yang terjadi di perusahaan dan juga yang banyak diperhatikan oleh investor di Bursa Efek Indonesia (BEI) adalah informasi mengenai kebijakan dividen perusahaan. Yang di maksud dengan kebijakan dividen adalah keputusan bagi perusahaan, apakah laba yang diperoleh perusahaan akan dibagikan kepada pemegang saham dalam bentuk dividen atau akan ditahan dalam bentuk laba ditahan guna pembiayaan investasi di masa yang akan datang.

Sedangkan dividen sendiri merupakan hak dari investor atas kepemilikan saham, dan merupakan kewajiban bagi emiten sebagai timbal balik penerimaan modal yang digunakan untuk kegiatan operasi perusahaan. Pembagian dividen kepada para pemegang saham pada saat ex-dividend date akan menyebabkan harga saham mengalami penurunan. Hal ini dikarenakan investor beranggapan bahwa pembagian dividen kepada para pemegang saham akan mengakibatkan posisi kas suatu perusahaanakan berkurang dan menyebabkan leverage (rasio hutang terhadap ekuitas) akan semakin besar. Selain itu, pengumuman pembagian dividen juga merupakan suatu sinyal dari pihak manajemen tentang prospek perusahaan di masa yang akan datang, 
dimana dengan adanya informasi pembagian dividen tersebut merupakan suatu sinyal tentang informasi yang berkaitan dengan prospek keuntungan yang akan diperoleh suatu perusahaan di masa yang akan datang.

Faktor yang mendasar bagi investor dalam berinvestasi adalah memperoleh keuntungan optimal dari penanaman modalnya berupa dividen ataupun capital gain. Informasi akan naik dan turunnya dividen yang dibagikan perusahaan termasuk informasi yang cukup penting bagi investor yang berkenaan dengan prospek keuntungan yang akan diperoleh suatu perusahaan di masa mendatang. Informasi ini menyebabkan kondisi investor dihadapkan pada ketidakpastian yang tinggi terhadap hasil kerja investasinya. Maka, informasi naik dan turun dapat dijadikan sebagai indikator untuk dapat memperkirakan ekspektasi keuntungan perusahaan di masa mendatang. Pembagian dividen kepada investor akan menyebabkan posisi kas suatu perusahaan semakin berkurang dan dapat mengakibatkan laverage (rasio antara hutag terhadap ekuitas) akan semakin meningkat. Peristiwa ini dapat mengakibatkan investor akan berpikir negatif terhadap perusahaan. Dalam teori Efficient Market Hypothesis, harga saham bereaksi terhadap informasi yang ada seperti, informasi tentang pembagian dividen yang dipercaya dapat mempengaruhi perilaku harga saham pada bursa akibat aksi investor yang menginginkan keuntungan dari kejadian tersebut. Investor biasanya memprediksi pembagian dividen akan berdampak pada harga saham, investor yang berkeinginan mendapat keuntungan cenderung akan memilih untuk tidak berada dalam posisi beli (long position). Dampaknya pada peristiwa ini harga saham tersebut akan mengalami penurunan sebanding dengan nilai return yang telah hilang.

Pembayaran dividen tunai memiliki empat tanggal penting yaitu tanggal pengumuman, tanggal ex-dividend, tanggal pencatatan dan tanggal pembayaran. Salah satu tanggal yang dapat berpengaruh terhadap harga pasar saham adalah tanggal exdividend sebab pada tanggal tersebut investor baru tidak berhak atas dividen yang akan didistribusikan. (Blandón, Blasco, \& Bosch, 2011), menyatakan pada pasar modal sempurna, harga saham akan turun tepat pada tanggal ex-dividend. Reaksi harga saham dapat diukur menggunakan abnormal return saham sebagai nilai dari perubahan harga. Abnormal return terjadi di seputar publikasi suatu informasi sebagai respon pasar terhadap informasi yang dipublikasikan dan direspon dengan cepat oleh investor.

Para investor dalam keputusan investasi pada saham tidak sekedar melihat perkembangan perusahaan beberapa tahun terakhir, tetapi juga dilihat prospeknya. Jika perusahaan mampu menciptakan kebijakan dividen yang optimal dalam arti adanya keseimbangan antara dividen dan pertumbuhan perusahaan yang berdampak pada kenaikan harga saham. Kenaikan dividen seringkali menyebabkan kenaikan harga saham, sementara pemotongan dividen umumnya menyebabkan penurunan saham. Peryataan tersebut diperkuat oleh pendapat Gordon dan Lintner (Brigham \& Houston, 2001) yang menyatakan bahwa sesungguhnya investor jauh lebih menghargai pendapatan yang diharapkan dari dividen dari pada pendapatan yang diharapkan dari keuntungan modal karena komponen hasil dividen risikonya lebih kecil dari pada komponen capital gain artinya investor lebih suka menerima pendapatan sekarang dari pada yang akan datang karena dihadapkan pada ketidakpastian. Hal ini dikarenakan pembagian dividen yang teratur menandakan perusahaan tersebut memiliki prospek cerah di masa mendatang.

Rumusan masalah dalam penelitian ini adalah sebagai berikut:

1. Bagaimanakah perbedaan Harga Saham sebelum pengumuman Pembagian Dividen dan sesudah pengumuman Pembagian Dividen Bank Pembangunan Daerah Jawa Timur Tbk Tahun 2015-2017? 
2. Bagaimanakah perbedaan Abnormal Return sebelum pengumuman Pembagian Dividen dan sesudah pengumuman Pembagian Dividen Bank Pembangunan Daerah Jawa Timur Tbk Tahun 2015-2017?

3. Bagaimanakah perbedaan Volume Perdagangan Saham sebelum pengumuman Pembagian Dividen dan sesudah pengumuman Pembagian Dividen Bank Pembangunan Daerah Jawa Timur Tbk Tahun 2015-2017?

\section{TINJAUAN PUSTAKA}

\section{Manajemen}

a. Pengertian Manajemen

Menurut Mary Parker Follet (Daft dan Marcic, 2007) dalam (Solihin, 2009) menegaskan pada dasarnya manajemen adalah, "the art of getting things done through people" (seni menyelesaikan pekerjaan melalui orang lain). Definisi ini mengandung arti bahwa para manager mencapai tujuantujuan organisasi melalui pengaturan orang-orang lain untuk melaksanakan berbagai tugas yang mungkin diperlukan, atau berarti dengan tidak melakukan tugas-tugas itu sendiri.

b. Fungsi-Fungsi Manajemen

Dari definisi Terry itulah bisa kita lihat fungsi-fungsi manajemen. Berikut ini adalah fungsi-fungsi manajemen menurut Terry:

1) Perencanaan (planning) yaitu sebagai dasar pemikiran dari tujuan dan penyusunan langkah-langkah yang akan dipakai untuk mencapai tujuan. Merencanakan berarti mempersiapkan segala kebutuhan, memperhitungkan matang-matang apa saja yang menjadi kendala, dan merumuskan bentuk pelaksanaan kegiatan yang bermaksud untuk mencapai tujuan.

2) Pengorganisasian (organization) yaitu sebagai cara untuk mengumpulkan orang-orang dan menempatkan mereka menurut kemampuan dan keahliannya dalam pekerjaan yang sudah direncanakan.

3) Penggerakan (actuating) yaitu untuk menggerakkan organisasi agar berjalan sesuai dengan pembagian kerja masing-masing serta menggerakkan seluruh sumber daya yang ada dalam organisasi agar pekerjaan atau kegiatan yang dilakukan bisa berjalan sesuai rencana dan bisa mencapai tujuan.

4) Pengawasan (controlling) yaitu untuk mengawasi apakah gerakan dari organisasi ini sudah sesuai dengan rencana atau belum. Serta mengawasi penggunaan sumber daya dalam organisasi agar bisa terpakai secara efektif dan efisien tanpa ada yang melenceng dari rencana.

2. Prinsip-Prinsip Manajemen

Asas (prinsip) merupakan suatu pernyataan fundamenta atau kebenaran umum yang dapat dijadikan pedoman pemikiran dan tindakan. Asas-asas muncul dari hasil penelitian dan pengamalan. Asas adalah dasar tetapi bukanlah sesuatu yang absolut dan mutlak. Artinya penerapan asas harus mempertimbangkan keadaan khusus dan keadaan yang berubah-ubah. (Hasibuan, 2011)(Hasibuan, 2011:9). 
3. Manajemen Keuangan

a. Pengertian Manajemen Keuangan

(Salamun \& Isworo, 2013) Manajemen keuangan atau sering disebut pembelanjaan perusahaan dapat diartikan sebagai semua aktivitas perusahaan yang berhubungan dengan berbagai usaha untuk mendapatkan dana perusahaan dengan biaya yang murah, yang kemudian dana tersebut digunakan dan dialokasikan secara efisien.

b. Tujuan Manajemen Keuangan

Tujuan manajemen keuangan adalah meningkatkan kesejahteraan para pemegang saham dan dapat diperlihatkan dalam wujud semakin tingginya harga saham perusahaan yang merupakan pencerminan dari keputusankeputusan investor, pendanaan, dan kebijakan dividen.

Dalam mencapai sasaran memaksimalkan kemakmuran para pemegang saham adalah laba per lembar saham (earning per share), sehingga kenaikan harga saham secara real akan mencerminkan kenaikan nilai perusahaan.

c. Fungsi Manajemen Keuangan

Fungsi Manajemen Keuangan tidak bisa dipisahkan dengan fungsi perusahaan yang lain, seperti fungsi pemasaran, produksi, sumber daya manusia maupun akutansi, kegagalan dalam mendapatkan sumber dana akan menghambat proses produksi, program pemasaran dan dalam mempekerjakan sumber daya manusia yang ahli, sehingga akan mengakibatkan kerugian perusahaan secara keseluruhan.

Manajemen keuangan mempunyai 3 fungsi yang harus dilakukan oleh perusahaan yakni :

1) Keputusan Investasi, bagaimana manajemen keuangan harus menghasilkan dana kedalam bentuk-bentuk investasi untuk mendapatkan keuntungan di masa yang akan datang.

2) Keputusan Pendanaan sebagai kebijakan suatu modal. Dalam hal ini manager keuangan mempertimbangkan dan menganalisa kombinasi dari sumber-sumber dana secara ekonomis guna membelanjakan kebutuhan-kebutuhan investasi serta kegiatan perusahaan.

3) Keputusan Dividen :

a) Menentuhkan persentase laba yang dibagikan kepada para pemegang saham dalam bentuk cash dividen,

b) Stabilitas dividen yang dibagikan,

c) Dividen saham (Stock Dividend),

d) Pemecahan saham (Stock Split).

4. Pasar Modal

a. Pengertian Pasar Modal

Menurut (UU RI No. 8, 1995), Pasar Modal adalah kegiatan yang bersangkutan dengan penawaran umum dan perdagangan efek, perusahaan publik yang berkaitan dengan efek yang diterbitkannya, serta lembaga dan profesi yang berkaitan dengan efek.

b. Fungsi Pasar Modal

Pasar modal memiliki beberapa fungsi strategis yang membuat lembaga ini memiliki daya tarik, tidak saja bagi pihak yang memerluhkan dana (borrowers) dan pihak yang meminjamkan dana (lenders), tetapi juga bagi pemerintah. Berikut beberapa fungsi pasar modal antara lain : 
1) Sebagai Sumber Penghimpun Dana

2) Sebagai Alternatif Investasi para Pemodal

3) Sebagai Pendorong Perkembangan Investasi

c. Manfaat Pasar Modal

Manfaat keberadaan pasar modal Indonesia menurut (Simatupang, 2010) antara lain:

1) Manfaat Pasar Modal Bagi Emiten

Manfaat pasar modal Indonesia bagi emiten adalah sebagai sumber pembiayaan untuk kegiatan pengembangan usaha atau untuk kegiatan investasi perusahaan yang memerlukan dana yang besar dalam jumlah ratusan miliar atau triliunan rupiah. Serta pengembalian utang perusahaan yang bersifat jangka panjang dalam sistem pembiayaan pasar modal dibandingkan dengan perbankan merupakan manfaat bagi perusahaan, karena secara teoritis bagian keuangan perusahaan akan lebih optimal memanfaatkan dana kewajiban pembayaran utang jangka panjang.

2) Manfaat Pasar Modal Bagi Investor

Manfaat pasar modal bagi investor adalah sebagai alternatif investasi yang menjanjikan pendapatan yang sangat menarik bagi para pemodal. Apabila para pemodal menerapkan prinsip-prinsip investasi yang baik yang disesuaikan dengan kondisi keuangan dan tujuan pribadi maka investasi di pasar modal dapat memberikan tingkat pendapatan yang menarik karena secara umum akan selalu memberikan hasil yang diharapkan.

3) Manfaat Pasar Modal Bagi Perekonomian Nasional

Manfaat pasar modal bagi perekonomian nasional adalah memberikan peluang sebagai sumber pendapatan dan pembiayaan yang sangat potensil bagi negara. Adapun sumber pendapatan berupa penerimaan pajak secara langsung bagi negara atas setiap transaksi perdagangan efek di pasar modal baik dalam transaksi saham maupun transaksi surat utang obligasi.

\section{Investasi}

a. Pengertian Investasi

Menurut Frank J. Fabozzi manajemen investasi adalah proses pengelolaan uang. Smith \& skounsen aktifitas investasi adalah transaksi dan kejadian pembelian, penjualan efek (tidak termasuk ekuivalen), bangunan, dan peralatan.

b. Tujuan Investasi

Untuk mencapai suatu efektifitas dan efesiensi dalam keputusan maka diperlukan ketegangan akan tujuan yang diharapkan. Begitu pula halnya dalam bidang investasi kita perlu menetapkan tujuan yang hendak dicapai yaitu :

1) Terciptanya keberlanjutan (continuity) dalam investasi tersebut;

2) Terciptanya profit yang maksimum atau keuntungan yang diharapkan (profit actual);

3) Terciptanya kemakmuran bagi para pemegang saham;

4) Turut memberikan adil bagi pembangunan bangsa.

c. Bentuk-bentuk Investasi
1) Real investment 
Investasi nyata secara umum melibatkan aset berwujud, seperti tanah, mesin-mesin, atau pabrik.

2) Financial investment

Investasi keuangan melibatkan kontrak tertulis, seperti saham biasa (common stock) dan obligasi (bond).

d. Tipe-tipe Investasi

Pada saat seseorang pembisnis atau mereka memiliki kelebihan dana dan ingin berinvestasi maka ia dapat memilih dan memutuskan tipe aktifitas keuangan seperti apa yang akan dipilihnya. Dalam hal ini ada dua tipe investasi yang dapat dipilihnya yaitu :

1) Direct Invesment

Investasi langsung adalah mereka yang memiliki dana dapat langsung berinvestasi dengan membeli secara langsung suatu aktiva keuangan dari suatu perusahaan yang dapat dilakukan baik melalui perantara atau berbagai cara lain.

2) Indirect Invesment

Investasi tidak langsung adalah mereka yang memiliki kelebihan dana dapat melakukan keputusan investasi dengan tidak terlibat secara langsung atau pembelian aktiva keuangan cukup hanya dengan memegang dalam bentuk saham atau obligasi saja.

e. Proses Investasi

Secara umum proses manajemen investasi meliputi 5 (lima) langkah :

1) Menetapkan sasaran investasi;

2) Membuat kebijakan investasi;

3) Memilih strategi portofolio;

4) Memilih asset;

5) Mengukur dan mengevaluasi kinerja.

6. Saham

a. Pengertian Saham

Saham adalah

1) Tanda bukti penyertaan kepemilikan modal/dana pada suatu perusahaan.

2) Kertas yang tercantum dengan jelas nilai nominal, nama perusahaan dan diikuti dengan hak dan kewajiban yang dijelaskan kepada setiap pemegangnya.

3) Persediaan yang siap untuk dijual.

b. Jenis-jenis Saham

1) Common Stock (Saham Biasa)

Common stock (saham biasa) adalah suatu surat berharga yang dijual oleh suatu perusahaan yang menjelaskan nilai nominal (rupiah, dolar, yen, dan sebagainya) dimana pemegangnya diberi hak untuk mengikuti RUPS (Rapat Umum Pemegang Saham) dan RUPSLB (Rapat Umum Pemegang Saham Luar Biasa) serta berhak untuk menentukan membeli right issue (penjualan saham terbatas) atau tidak, yang selanjutnya pada akhir tahun akan memperoleh keuntungan dalam bentuk deviden. 
2) Preferred Stock (Saham Istimewa)

Preferred Stock (Saham Istimewa) adalah suatu surat berharga yang dijual oleh suatu perusahaan yang menjelaskan nilai nominal (rupiah, dolar, yen, dan sebagainya) dimana pemegangnya akan memperoleh pendapatan tetap dalam bentuk dividen yang akan diterima setiap kuartal (tiga bulan).

\section{Corporate Action}

Corporate action adalah tindakan yang dilakukan oleh perusahaan yang bobotnya cukup material sehingga mempunyai kemungkinan mempengaruhi harga saham dari perusahaan yang bersangkutan di bursa efek (Robert Ang, 1995). (Hadi, 2013).

8. Dividen

\section{a. Pengertian Dividen}

Dividen adalah pembagian keuntungan yang diberikan perusahaan penerbit saham tersebut atas keutungan yang dihasilkan perusahaan. Dividen diberikan setelah mendapat persetujuan dari pemegang saham dalam RUPS.

Istilah Pembayaran Dividen :

1) Cum Date. Cum date adalah tanggal terakhir di mana saham di perdagangkan masih memperoleh hak atas dividen, hak memesan efek terlebih dahulu (HMETD), dan waran. Disebut juga tanggal deklarasi merupakan tanggal disetujuinya pembayaran dividen oleh Dewan Direksi. Untuk kepentingan akuntansi, dividen diakui pada saat cum date. (Bapepam, 2015)

2) Ex Date. Ex date adalah tanggal di mana investor yang membeli saham pada hari itu tidak berhak mendapatkan dividen.

3) Recording Date. Recording date merupakan tanggal terakhir dari pendaftaran atas pemilikan saham dalam daftar pemegang saham perusahaan. Pendaftaran ini biasanya berhubungan dengan pembagian dividen, right issue, pemberian saham bonus/dividen saham dan hak untuk hadir dalam Rapat Umum Pemegang Saham. Disebut juga tanggal pencatatan, merupakan tanggal dimana pendaftaran penerima dividen ditutup. Hanya pemegang saham yang terdaftar pada tanggal ini yang berhak untuk menerima dividen. (Bapepam, 2015)

4) Payment Date. Disebut juga tanggal pembayaran, merupakan tanggal dimana dividen yang telah dideklarasikan akan dibayarkan. (Tandelilin, 2017:32-34)

b. Jenis-jenis dividen dan pembayarannya

Ada beberapa jenis dividen yang merupakan realisasi dari pembayaran dividen, yaitu :

1) Dividen tunai (cash dividend) yaitu dividen yang dinyatakan dan dibayarkan pada jangka waktu tertentu dan dividen tersebut berasal dari dana yang diperoleh secara legal. Dividen ini dapat bervariasi dalam jumlah bergantung kepada keuntungan perusahaan.

2) Dividen property (property dividends) yaitu suatu distribusi keuntungan perusahaan dalam bentuk property atau barang.

3) Dividen likuidasi (liquidating dividen) yaitu distribusi kekayaan perusahaaan kepada pemegang saham dalam hal perusahaan tersebut dilikuidasi. 
9. Harga Saham

Pada hakikatnya, harga saham perusahaan ditentukan oleh prospek perusahaan tersebut dimasa mendatang. Harga saham adalah cerminan dari pengelolaan perusahaan yang baik oleh manajemen untuk menciptakan dan memanfaatkan prospek usaha, sehingga memperoleh keuntungan dan mampu memenuhi tanggung jawabnya terhadap pemilik, karyawan, masyarakat, dan pemerintah (stakeholders).

10. Volume Perdagangan

Volume pasar adalah bukti besarnya perhatian investor. Volume adalah fungsi penawaran dan permintaan atas saham yang menunjukkan kekuatan dan kelemahan pasar saham tertentu. Investor sangat berhasrat membeli atau menjual berdasarkan daya serap terhadap volume saham yang diperdagangkan. Sebagai rule, pasar dianggap kuat apabila volume perdagangan meningkat atau dianggap lemah apabila volume menurun saat pasar lesu. (Siahaan, 2011).

11. Abnormal Return Saham

Menurut (Hartono, 2016) dalam bukunya mengatakan efisiensi pasar diuji dengan melihat return tidak wajar atau return tak normal (abnormal return) yang terjadi. Pasar dikatakan tidak efisien jika satu atau beberapa pelaku pasar dapat menikmati return yang tidak normal dalam jangka waktu yang cukup lama. Abnormal return atau excess return merupakan kelebihan dari return yang sesungguhnya terjadi terhadap return normal. Return normal merupakan return ekspektasi (return yang diharapkan oleh investor). Dengan demikian return tak normal (abnormal return) adalah selisih antara return sesungguhnya yang terjadi dengan return ekspetasi.

\section{Kerangka Konsep}

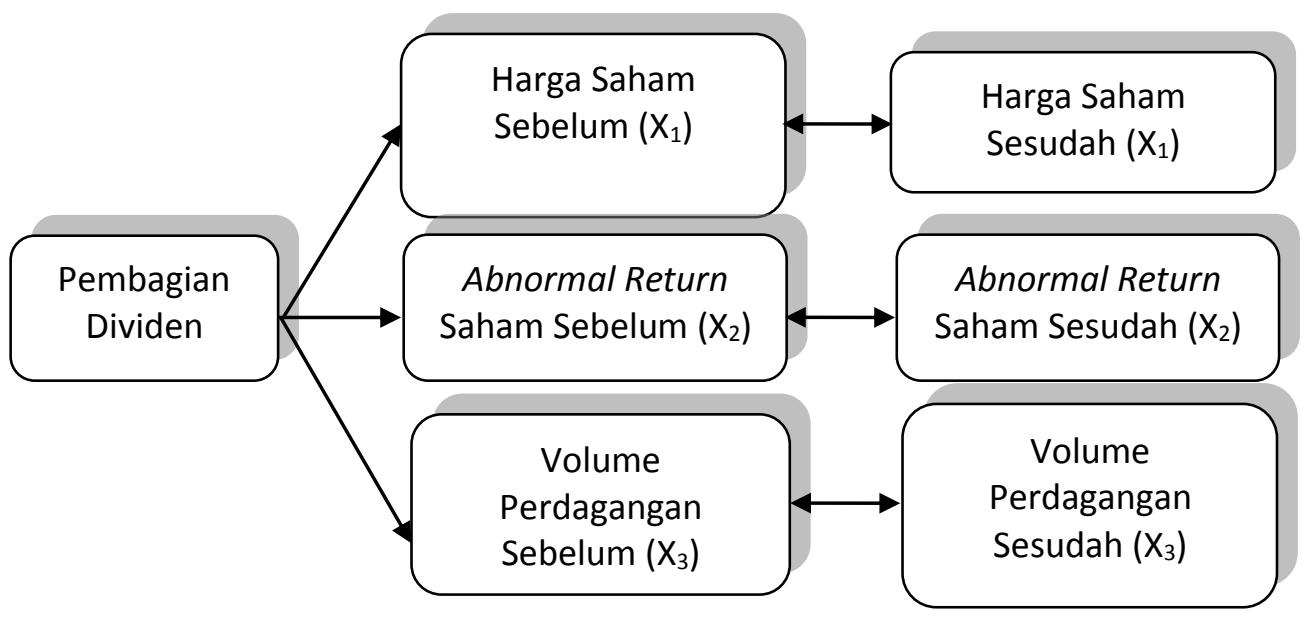

\section{HIPOTESIS}

$\mathrm{H}_{1}$ : Terdapat perbedaan Harga Saham sebelum dan sesudah Pembagian Dividen pada Bank Pembangunan Daerah Jawa Timur Tbk Tahun 2015-2017;

$\mathrm{H}_{2}$ : Terdapat perbedaan Abnormal Return Saham sebelum dan sesudah Pembagian Dividen pada Bank Pembangunan Daerah Jawa Timur Tbk Tahun 2015-2017;

$\mathrm{H}_{3}$ : Terdapat perbedaan Volume Perdagangan sebelum dan sesudah Pembagian Dividen pada Bank Pembangunan Daerah Jawa Timur Tbk Tahun 2015-2017; 


\section{METODE PENELITIAN}

Dalam bukunya (Yusuf, 2014) dimana dijelaskan bahwa penelitian (research) sebagai salah satu cara untuk menyelesaikan suatu masalah atau mencari jawab dari persoalan yang dihadapi secara ilmiah, menggunakan cara berpikir reflektif, berpikir keilmuan dengan prosedur yang sesuai dengan tujuan dan sifat penyelidikan. Penelitian ilmiah menggunakan langkah-langkah yang sistematis dan terkendali, bersifat hati-hati dan logis, objektif dan empiris serta terarah pada sasaran yang ingin dipecahkan. Penelitian yang dilaksanakan itu hendaknya mampu menjawab masalah yang ada, mengungkapkan secara tepat atau memprediksi secara benar.

Berdasarkan karakteristik permasalahan yang membahas ada tidaknya dampak pengumuman dividen terhadap perubahan harga, abnormal return, dan volume perdagangan saham sebelum dan sesudah pembagian dividen Bank Pembangunan Daerah Jawa Timur Tbk tahun 2015-2017. Dimana jenis penelitian yang digunakan dalam penelitian ini adalah jenis penelitian kuantitatif (quantitative research).

\section{Definisi Operasional Variabel}

Harga Saham

Data Harga Saham yang digunakan dalam penelitian ini adalah harga saham Bank Pembangunan Daerah Jawa Timur Tbk di Bursa Efek Indonesia serta diakses melalui website www.idx.co.id, https://stockbit.com, www.finance.yahoo.com. Dimana data Harga Saham yang digunakan adalah data harga saham penutupan harian (closing price) selama periode tahun 2015-2017 pada 60 hari seputar tanggal pengumuman.

\section{Abnormal Return}

Data Abnormal Return yang digunakan dalam penelitian ini adalah perhitungan Abnormal Return harga saham Bank Pembangunan Daerah Jawa Timur Tbk di Bursa Efek Indonesia serta diakses melalui website www.idx.co.id, https://stockbit.com, www.finance.yahoo.com. Dimana data Abnormal Return yang digunakan adalah data Abnormal Return dari harga saham penutupan harian (closing price) selama periode tahun 2015-2017 pada 60 hari seputar tanggal pengumuman;

\section{Volume Perdagangan Saham}

Data Volume Perdagangan Saham yang digunakan dalam penelitian ini adalah Volume Perdagangan Saham Bank Pembangunan Daerah Jawa Timur Tbk di Bursa Efek Indonesia serta diakses melalui www.finance.yahoo.com. Dimana data Volume Perdagangan Saham yang digunakan adalah data Volume Perdagangan Saham dari Volume Perdagangan Saham penutupan harian (closing price) selama periode tahun 2015-2017 pada 60 hari seputar tanggal pengumuman.

\section{Teknik Analisis Data}

Penelitian ini menggunakan analisis data kuantitatif atau data statistik, karena data-data diperoleh diolah dan diuji dengan menggunakan statistic dan data-datanya dalam bentuk angka-angka (Ayati:2000).

\section{Studi Peristiwa}

Studi peristiwa merupakan studi yang mempelajari reaksi investor terhadap suatu peristiwa yang informasinya dipublikasikan sebagai suatu pengumuman. Periode peristiwa waktu yang digunakan dalam penelitian ini dibagi menjadi dua yaitu : 
a. Periode peristiwa selama 60 hari kerja yaitu 40 hari kerja sebelum tanggal pengumuman pembagian dividen ;

b. Periode kejadian saat tanggal pengumuman pembagian dividen ;

c. Selama 20 hari kerja sesudah pengumuman pembagian dividen hingga tahun 2015-2017.

2. Return Saham

Menentukan besarnya return pada periode peristiwa. Rumus dari return saham adalah sebagai berikut :

$$
\mathrm{R}_{\mathrm{i}, \mathrm{t}}=\frac{P_{i t}-P_{i t-1}}{P_{i t-1}}
$$

Dimana :

$\mathrm{R}_{\mathrm{i}, \mathrm{t}} \quad=$ Return saham ke i pada hari ke-t

$\mathrm{P}_{\mathrm{it}} \quad=$ Harga saham ke-i pada hari ke-t

$\mathrm{P}_{\mathrm{it}-1}=$ Harga saham ke-i pada hari ke-i-t

3. Return Expectation

Menentukan return ekspektasi pada periode kejadian

$$
E(\text { Rit })=\frac{\sum_{\mathrm{t}=-5}^{\mathrm{t}=-105} \mathrm{fit}}{100}
$$

4. Abnormal Return

Menentukan abnormal return pada periode jendela

$$
\text { ARit }=\text { Rit }-\mathrm{Rm}_{\mathrm{i}}
$$

Menentukan rata-rata abnormal return pada rumus sebagai berikut ;

$$
\text { RRTN }_{\mathrm{t}}=\frac{\sum_{\mathrm{i}=1}^{\mathrm{k} A R i t}}{\mathrm{k}}
$$

Melakukan pengujian statistik terhadap return tidak normal. Teknik pengujian yang dilakukan adalah pengujian $\mathrm{t}$ (t-test). Aktivitas volume perdagangan saham dilihat dengan menggunakan indikator Trading Volume Activity (TVA) dengan rumusan sebagai berikut :

$$
T V A=\frac{\text { Saham perusahaan i yang diperdagangkan pada waktu } \mathrm{t}}{\text { Saham perusahaan iyang beredar pada waktu } \mathrm{t}}
$$

TVA digunakan untuk melihat apakah preferensi investor secara individual menilai pengumuman pembagian dividen sebagai positif atau negative untuk membuat keputusan perdagangan saham diatas keputusan perdagangan yang normal. Setelah TVA masing-masing saham diketahui, kemudian dihitung ratarata volume perdagangan untuk semua sampel dengan rumusan sebagai berikut :

$$
\text { dimana : } \text { RRTN }_{\mathrm{t}}=\frac{\substack{\mathrm{k} \text { TVA } \\ \mathrm{i}=1}}{\mathrm{n}}
$$


$\mathrm{RRTN}_{\mathrm{t}}=$ rata-rata return tidak normal (average abnormal return) pada hari ke $-\mathrm{t}$

$\mathrm{RTN}_{\mathrm{it}} \quad=$ rata-rata return tidak normal (average abnormal return) untuk sekuritas ke-i pada hari ke-t

$\mathrm{k}=$ jumlah sekuritas yang terpengaruh oleh pengumuman deviden

5. Uji Beda Dua Rata-Rata Berpasangan (t-test)

Uji hipotesis ini dilakukan untuk mengetahui ada tidaknya pengaruh variabel independen $(\mathrm{X})$ dengan variabel dependen $(\mathrm{Y})$ secara parsial.

$\mathrm{H}_{0}$ : Variabel independen $(\mathrm{X})$ tidak memiliki pengaruh signifikan secara parsial terhadap variabel dependen $(\mathrm{Y})$

$\mathrm{H}_{1}$ : Variabel independen (X) memiliki pengaruh signifikan secara parsial terhadap variabel dependen $(\mathrm{Y})$

Melakukan pengujian data dengan menggunakan metode Paired Sample T Test pada masing-masing variabel dependent untuk mengetahui ada tidaknya perbedaan Harga Saham, Abnormal Return dan Volume Perdagangan Saham sebelum dan sesudah perubahan fraksi.

a. T-Hitung

$$
=\frac{\sum D}{\sqrt{\frac{N\left(\sum D^{2}\right)-\left(\sum D\right)}{N-1}}}
$$

Menentukan kriteria hipotesis :

Ho diterima jika sig-t (probabilitas) $>0,05$

Ha diterima jika sig-t (probabilitas) $<0,05$

\section{HASIL DAN PEMBAHASAN}

Hasil Perhitungan Harga Saham Sebelum Dan Sesudah Pengumuman Pembagian Dividen Tahun 2015-2017

Uji Beda Dua Rata-Rata Berpasangan (T-Test) Harga Saham 2015

\begin{tabular}{|l|r|r|}
\hline t-Test: Two-Sample Assuming Equal Variances \\
\hline & Before 2015 & After 2015 \\
\hline Mean & 540.37500 & 492.70000 \\
Variance & 168.44551 & 175.48421 \\
Observations & 40 & \\
Pooled Variance & 170.75129 & \\
Hypothesized Mean Difference & 0 & \\
df & 58 & \\
t Stat & 13.32227 & \\
P(T<=t) one-tail & $1.34583 \mathrm{E}-19$ & \\
$\mathrm{t}$ Critical one-tail & 1.67155 & \\
$\mathrm{P}(\mathrm{T}<=\mathrm{t})$ two-tail & $2.69165 \mathrm{E}-19$ & \\
$\mathrm{t}$ Critical two-tail & 2.00172 & \\
\hline
\end{tabular}


Sumber : data diolah penulis, 2018

Dengan menggunakan dasar keputusan seperti diatas, diketahui berdasarkan $\alpha=$ $5 \%$ diperoleh nilai probabilitas t-test sebesar 13.32227. Maka dapat disimpulkan probabilitas $t$-test $13.32227>t$-table 1,67155 , yang artinya menolak $\mathrm{h}_{0}$. Sehingga hipotesis pertama yang diajukan menyatakan bahwa terdapat perbedaan harga saham sebelum pengumuman pembagian dividen dan sesudah pengumuman pembagian dividen pada Bank Pembangunan Daerah Jawa Timur Tbk di Bursa Efek Indonesia tahun 2015, dapat diterima.

\section{Uji Beda Dua Rata-Rata Berpasangan (T-Test)} Harga Saham 2016

\begin{tabular}{|l|r|r|}
\hline t-Test: Two-Sample Assuming Equal Variances \\
\hline & Before 2016 & After 2016 \\
\hline Mean & 440.20000 & 418.50000 \\
Variance & 107.65128 & 89.94737 \\
Observations & 40 & 20 \\
Pooled Variance & 101.85172 & \\
Hypothesized Mean Difference & 0 & \\
Df & 58 & \\
t Stat & 7.85136 & \\
P(T<=t) one-tail & $5.43681 \mathrm{E}-11$ & \\
$\mathrm{t}$ Critical one-tail & 1.67155 & \\
$\mathrm{P}(\mathrm{T}<=\mathrm{t})$ two-tail & $1.08736 \mathrm{E}-10$ & \\
$\mathrm{t}$ Critical two-tail & 2.00172 & \\
\hline
\end{tabular}

Sumber : data diolah penulis, 2018

Dengan menggunakan dasar keputusan seperti diatas, diketahui berdasarkan $\alpha=$ 5\% diperoleh nilai probabilitas t-test sebesar 7.85136. Maka dapat disimpulkan probabilitas $t$-test $7.85136>t$-table 1.67155 , yang artinya menolak $\mathrm{h}_{0}$. Sehingga hipotesis pertama yang diajukan menyatakan bahwa terdapat perbedaan harga saham sebelum pengumuman pembagian dividen dan sesudah pengumuman pembagian dividen pada Bank Pembangunan Daerah Jawa Timur Tbk di Bursa Efek Indonesia tahun 2016, dapat diterima.

Uji Beda Dua Rata-Rata Berpasangan (T-Test) Harga Saham 2017

\begin{tabular}{|l|r|r|}
\hline t-Test: Two-Sample Assuming Equal Variances \\
\hline Mean & Before 2017 & \multicolumn{1}{|c|}{ After 2017 } \\
Variance & 604.25000 & 565 \\
Observations & 530.19231 & 84.21053 \\
Pooled Variance & 40 & 20 \\
Hypothesized Mean & 384.09483 & \\
Difference & 0 & \\
df & 58 &
\end{tabular}




\begin{tabular}{|l|r|} 
t Stat & 7.31290 \\
$\mathrm{P}(\mathrm{T}<=\mathrm{t})$ one-tail & $4,36676 \mathrm{E}-10$ \\
t Critical one-tail & 1,67155 \\
$\mathrm{P}(\mathrm{T}<=\mathrm{t})$ two-tail & $8,73352 \mathrm{E}-10$ \\
t Critical two-tail & 2,00172
\end{tabular}

Sumber : data diolah penulis, 2018

Dengan menggunakan dasar keputusan seperti diatas, diketahui berdasarkan $\alpha=$ $5 \%$ diperoleh nilai probabilitas t-test sebesar 7.31290. Maka dapat disimpulkan probabilitas t-test $7.31290>t$-table 1.67155 , yang artinya menolak $\mathrm{h}_{0}$. Sehingga hipotesis pertama yang diajukan menyatakan bahwa terdapat perbedaan harga saham sebelum pengumuman pembagian dividen dan sesudah pengumuman pembagian dividen pada Bank Pembangunan Daerah Jawa Timur di Bursa Efek Indonesia tahun 2017, dapat diterima.

\section{Hasil Perhitungan Abnormal Return Sebelum Dan Sesudah Pengumuman Pembagian Dividen Tahun 2015-2017}

Uji Beda Dua Rata-Rata Berpasangan (T-Test) Abnormal Return 2015

\begin{tabular}{|l|r|r|}
\hline $\mathrm{t}$-Test: Two-Sample Assuming Equal Variances \\
\hline & AR Before & \multicolumn{1}{|c|}{ AR After } \\
\hline Mean & 0.00039 & 0.00182 \\
Variance & 0.00020 & 0.00044 \\
Observations & 40 & 20 \\
Pooled Variance & 0.00028 & \\
Hypothesized Mean Difference & 0 & \\
Df & 58 & \\
t Stat & -0.31401 & \\
P(T<=t) one-tail & 0.37732 & \\
t Critical one-tail & 1.67155 & \\
P(T<=t) two-tail & 0.75464 & \\
$\mathrm{t}$ Critical two-tail & 2.00172 & \\
\hline
\end{tabular}

Sumber : data diolah penulis, 2018

Dengan menggunakan dasar keputusan seperti diatas, diketahui berdasarkan $\alpha=$ $5 \%$ diperoleh nilai probabilitas t-test sebesar (0.1401). Maka dapat disimpulkan probabilitas $t$-test $(0.31401)>t$-table 1.67155 , yang artinya gagal menolak $\mathrm{h}_{0}$. Sehingga hipotesis kedua yang diajukan menyatakan bahwa tidak terdapat perbedaan abnornal return sebelum pengumuman pembagian dividen dan sesudah pengumuman pembagian dividen pada Bank Pembangunan Daerah Jawa Timur Tbk di Bursa Efek Indonesia tahun 2015, tidak dapat diterima. 
Uji Beda Dua Rata-Rata Berpasangan (T-Test) Abnormal Return 2016

\begin{tabular}{|l|r|r|}
\hline t-Test: Two-Sample Assuming Equal Variances \\
\hline & AR Before & \multicolumn{1}{|c|}{ AR After } \\
\hline Mean & -0.00065 & 0.00318 \\
Variance & 0.00026 & 0.00016 \\
Observations & 40 & 20 \\
Pooled Variance & 0.00023 & \\
Hypothesized Mean & & \\
Difference & 0 & \\
df & 58 & \\
t Stat & -0.93380 & \\
P(T<=t) one-tail & 0.17714 & \\
t Critical one-tail & 1.67155 & \\
P(T<=t) two-tail & 0.35428 & \\
t Critical two-tail & 2.00172 & \\
\hline
\end{tabular}

Sumber : data diolah penulis, 2018

Dengan menggunakan dasar keputusan seperti diatas, diketahui berdasarkan $\alpha=$ $5 \%$ diperoleh nilai probabilitas t-test sebesar (0.93380). Maka dapat disimpulkan probabilitas $t$-test $(0.93380)>t$-table 1.67155 , yang artinya gagal menolak $\mathrm{h}_{0}$. Sehingga hipotesis kedua yang diajukan menyatakan bahwa tidak terdapat perbedaan abnornal return sebelum pengumuman pembagian dividen dan sesudah pengumuman pembagian dividen pada Bank Pembangunan Daerah Jawa Timur Tbk di Bursa Efek Indonesia tahun 2016, tidak dapat diterima.

Uji Beda Dua Rata-Rata Berpasangan (T-Test) Abnormal Return 2017

\begin{tabular}{|l|r|r|}
\hline t-Test: Two-Sample Assuming Equal Variances \\
\hline & AR Before & \multicolumn{1}{|c|}{ AR After } \\
\hline Mean & 0.00185 & -0.00289 \\
Variance & 0.00030 & 0.00014 \\
Observations & 40 & 20 \\
Pooled Variance & 0.00024 & \\
Hypothesized Mean Difference & 0 & \\
df & 58 & \\
t Stat & 1.11126 & \\
P(T<=t) one-tail & 0.13552 & \\
t Critical one-tail & 1.67155 & \\
P $(\mathrm{T}<=t)$ two-tail & 0.27104 & \\
t Critical two-tail & 2.00172 & \\
\hline
\end{tabular}

Sumber : data diolah penulis, 2018 
Dengan menggunakan dasar keputusan seperti diatas, diketahui berdasarkan $\alpha=$ $5 \%$ diperoleh nilai probabilitas t-test sebesar 1.111255. Maka dapat disimpulkan probabilitas $t$-test $1.11126>$ t-table 1.67155 , yang artinya gagal menolak $\mathrm{h}_{0}$. Sehingga hipotesis kedua yang diajukan menyatakan bahwa tidak terdapat perbedaan abnornal return sebelum pengumuman pembagian dividen dan sesudah pengumuman pembagian dividen pada Bank Pembangunan Daerah Jawa Timur Tbk di Bursa Efek Indonesia tahun 2017, tidak dapat diterima.

\section{Hasil Perhitungan Volume Perdagangan Sebelum Dan Sesudah Pengumuman Pembagian Dividen Tahun 2015-2017}

Uji Beda Dua Rata-Rata Berpasangan (T-Test) Volume Perdagangan Saham Tahun 2015

\begin{tabular}{|l|r|r|}
\hline \multicolumn{1}{|c|}{ t-Test: Two-Sample Assuming Equal Variances } \\
\hline & Before 2015 & \multicolumn{1}{c|}{ After 2015 } \\
\hline Mean & 14509218 & 17606635 \\
Variance & $9.94597 \mathrm{E}+13$ & $1.24575 \mathrm{E}+14$ \\
Observations & 40 & 20 \\
Pooled Variance & $1.07687 \mathrm{E}+14$ & \\
Hypothesized Mean Difference & 0 & \\
Df & 58 & \\
t Stat & -1.08990 & \\
P(T<=t) one-tail & 0.14013 & \\
t Critical one-tail & 1.67155 & \\
P $(\mathrm{T}<=t)$ two-tail & 0.28026 & \\
t Critical two-tail & 2.00172 & \\
\hline
\end{tabular}

Sumber : data diolah penulis, 2018

Dengan menggunakan dasar keputusan seperti diatas, diketahui berdasarkan $\alpha=$ $5 \%$ diperoleh nilai probabilitas t-test sebesar 1.08990. Maka dapat disimpulkan probabilitas $t$-test $1.08990>$ t-table 1.67155 , yang artinya gagal menolak $\mathrm{h}_{0}$. Sehingga hipotesis ketiga yang diajukan menyatakan tidak terdapat perbedaan volume sebelum pengumuman pembagian dividen dan sesudah pengumuman pembagian dividen pada Bank Pembangunan Daerah Jawa Timur Tbk di Bursa Efek Indonesia tahun 2015, tidak dapat diterima.

Uji Beda Dua Rata-Rata Berpasangan (T-Test) Volume Perdagangan Saham Tahun 2016

\begin{tabular}{|l|r|r|}
\hline \multicolumn{1}{|c|}{ t-Test: Two-Sample Assuming Equal Variances } \\
\hline Mean & Before 2016 & \multicolumn{1}{c|}{ After 2016 } \\
Variance & 6445865 & 9962125 \\
Observations & $8.75749 \mathrm{E}+13$ & $1.23841 \mathrm{E}+14$ \\
Pooled Variance & 40 & 20 \\
Hypothesized Mean Difference & $9.94551 \mathrm{E}+13$ &
\end{tabular}




\begin{tabular}{|l|r|} 
Df & 58 \\
t Stat & -1.28747 \\
$\mathrm{P}(\mathrm{T}<=\mathrm{t})$ one-tail & 0.10152 \\
t Critical one-tail & 1.67155 \\
$\mathrm{P}(\mathrm{T}<=\mathrm{t})$ two-tail & 0.20304 \\
$\mathrm{t}$ Critical two-tail & 2.00172 \\
\hline
\end{tabular}

Sumber : data diolah penulis, 2018

Dengan menggunakan dasar keputusan seperti diatas, diketahui berdasarkan $\alpha=$ 5\% diperoleh nilai probabilitas t-test sebesar (1.28747). Maka dapat disimpulkan probabilitas $t$-test $(1.28747)>t$-table 1.67155 , yang artinya gagal menolak $\mathrm{h}_{0}$. Sehingga hipotesis ketiga yang diajukan menyatakan tidak terdapat perbedaan volume sebelum pengumuman pembagian dividen dan sesudah pengumuman pembagian dividen pada Bank Pembangunan Daerah Jawa Timur Tbk di Bursa Efek Indonesia tahun 2016, tidak dapat diterima.

Uji Beda Dua Rata-Rata Berpasangan (T-Test) Volume Perdagangan Saham Tahun 2017

\begin{tabular}{|l|r|r|}
\hline \multicolumn{2}{|c|}{$\mathrm{t}$-Test: Two-Sample Assuming Equal Variances } \\
\hline Mean & Before 2017 & After 2017 \\
Variance & 84437938 & 25254475 \\
Observations & $6.40591 \mathrm{E}+15$ & $1.94496 \mathrm{E}+14$ \\
Pooled Variance & 40 & 20 \\
Hypothesized Mean Difference & $0.37113 \mathrm{E}+15$ & \\
df & 58 & \\
t Stat & 3.26868 & \\
P(T<=t) one-tail & 0.00091 & \\
t Critical one-tail & 1.67155 & \\
P(T<=t) two-tail & 0.00182 & \\
t Critical two-tail & 2.00172 & \\
\hline
\end{tabular}

Sumber : data diolah penulis, 2018

Dengan menggunakan dasar keputusan seperti diatas, diketahui berdasarkan $\alpha=$ $5 \%$ diperoleh nilai probabilitas t-test sebesar 3.26868. Maka dapat disimpulkan probabilitas $t$-test $3.26868>t$-table 1.67155 , yang artinya menolak $\mathrm{h}_{0}$. Sehingga hipotesis ketiga yang diajukan menyatakan terdapat perbedaan volume sebelum pengumuman pembagian dividen dan sesudah pengumuman pembagian dividen pada Bank Pembangunan Daerah Jawa Timur Tbk di Bursa Efek Indonesia tahun 2017, dapat diterima. 


\section{SIMPULAN DAN SARAN}

\section{Simpulan}

Berdasarkan hasil penelitian, maka simpulan yang dapat diambil mengenai ada atau tidaknya perbedaan Harga Saham, Abnormal Return, dan Volume Perdagangan Saham sebelum pembagian dividen dan sesudah pembagian dividen pada Bank Pembangunan Daerah Jawa Timur Tbk Tahun 2015-2017, adalah sebagai berikut :

1. Penelitian ini menggunakan emiten yang memiliki dividend yield yang tinggi. Dimana variabel-variabel yang digunakan adalah Harga Saham, Abnormal Return dan Volume Perdagangan Saham dengan menggunakan uji beda dua rata-rata berpasangan ( $t$-test).

2. Hasil penelitian variabel Harga Saham memiliki nilai probabilitas $t$-test 2015 , $t$ test 2016, dan $t$-test 2017 sebesar 13.32227, 7.85136 dan 7.31290 sehingga dapat disimpulkan probabilitas t-test 2015 sampai $2017>t$-table sebesar 1.67155. Artinya terdapat perbedaan harga saham sebelum pengumuman pembagian dividen dan sesudah pengumuman pembagian dividen pada Bank Pembangunan Daerah Jawa Timur Tbk di Bursa Efek Indonesia tahun 2015-2017.

3. Hasil penelitian variabel Abnormal Return memiliki nilai probabilitas t-test 2015, t-test 2016, dan t-test 2017 sebesar (0.31401), (0.93380), dan 1.11125 sehingga dapat disimpulkan probabilitas t-test 2015 sampai $t$-test $2017<t$-table 1.67155 . Artinya tidak terdapat perbedaan abnormal return sebelum pengumuman pembagian dividen dan sesudah pengumuman pembagian dividen Bank Pembangunan Daerah Jawa Timur Tbk di Bursa Efek Indonesia tahun 2015-2017.

4. Hasil penelitian variabel Volume Perdagangan Saham memiliki nilai probabilitas t-test 2015, t-test 2016, dan $t$-test 2017 sebesar (1.08990), (1.28747), dan 3.26868 sehingga dapat disimpulkan probabilitas t-test 2015, 2016, dan 2017 t-table sebesar 1,67155. Artinya tidak terdapat perbedaan volume perdagangan saham sebelum pengumuman pembagian dividen Bank Pembangunan Daerah Jawa Timur Tbk di Bursa Efek Indonesia tahun 2015-2017.

\section{Saran}

Setelah melakukan penelitian ini, peneliti mempunyai beberapa saran

1. Bagi Perusahaan, agar bisa meningkatkan kualitas informasi yang dimiliki karena informasi tentang perusahaan akan direspon oleh investor dalam berbagai bentuk, baik positif maupun negatif.

2. Bagi Peneliti selanjutnya, peneliti dapat menambahkan variabel pengukuran yang lain dan memperluas sampel penelitian agar diperoleh hasil yang lebih objektif.

3. Bagi Investor, diharapkan penelitian ini dapat dijadikan sebagai bahan informasi tambahan yang digunakan sebagai bahan pertimbangan investor dalam melakukan keputusan investasi di pasar modal dengan memperhatikan bagaimana kinerja suatu perusahaan yang tercermin pada reaksi pasar yang ada.

\section{DAFTAR PUSTAKA}

Blandón, J. G., Blasco, M. M., \& Bosch, J. A. (2011). Ex-dividend day returns when dividend and capital gains are taxed at the same rate. Finance a Uver-Czech Journal of Economics and Finance.

Brigham, E. F., \& Houston, J. F. (2001). Manajemen Keuangan (edisi 8.). Jakarta: Erlangga. 
Hadi, N. (2013). Pasar Modal : Acuan Teoritis dan Praktis Investasi di Instrumen Keuangan Pasar Modal (edisi pert.). Yogyakarta: Graha Ilmu.

Hartono, J. (2016). Teori Portofolio dan Analisis Investasi (edisi 10.). Yogyakarta: BPFE.

Hasibuan, M. S. (2011). Manajemen : Dasar, Pengertian, dan Masalah. Jakarta: Bumi Aksara.

Salamun, S., \& Isworo, F. . (2013). Manajemen Keuangan (investasi dan pembiayaan). Jakarta Selatan: Institute of Financial.

Siahaan, H. (2011). Lebih Untung Membeli Surat Utang Negara. Jakarta: Elex Media Komputindo.

Simatupang, M. (2010). Lembaga Keuangan Perbankan, Pasar Modal dan Lembaga Keuangan Lainya. Jakarta: Mitra Wacana Media.

Solihin, I. (2009). Pengantar Manajemen. Jakarta: Erlangga.

UU RI No. 8. (1995). Pasar Modal adalah ketentuan umum mengenai undang-undang Pasar Modal berisi tentang definisi, pengertian, serta aturan dan ketentuan mengenai aktivitas di pasar modal.

Yusuf, A. M. (2014). Metode Penelitian : Kuantitatif, Kualitatif dan Penelitian Gabungan (Edisi Pert.). Jakarta: Prenadamedia Group. 